\title{
Philosophy
}

Editor

RENFORD BAMBROUGH President of St. John's College, Cambridge and Sidgwick Lecturer in Philosophy, University of Cambridge

Published for the Royal Institute of Philosophy

The journal is concerned with the study of philosophy in all its branches: logic, metaphysics, epistemology, ethics, aesthetics, social and political philosophy and the philosophies of religion, science, history, language, mind and education. The journal is not committed to any particular school or method and contributors are expected to avoid needless technicality. There is a section on new books which includes reviews, book notes and a list of books received.

Subscription (until 31 December 1983) for four issues and two supplements $£ 44.00$. Single parts: $£ 8.00$. Members of the Royal Institute of Philosophy receive the journal free and may purchase the supplements if they wish. Membership costs $£ 13.50$ or $\$ 30.00$ (Students $£ 7$ or $\$ 15.00$ )

ISSN 0031-8205

\section{Royal Institute of Philosophy Lecture Series}

$\begin{array}{rll}\text { Volume } 1 & 1966 / 67 \text { Lectures } & \text { The Human Agent } \\ 2 & 1967 / 68 & \text { Talk of God } \\ 3 & 1968 / 69 & \text { Knowledge and Necessity } \\ 4 & 1969 / 70 & \text { The Proper Study } \\ 5 & 1970 / 71 & \text { Reason and Reality } \\ 6 & 1971 / 72 & \text { Philosophy and the Arts } \\ 7 & 1972 / 73 & \text { Understanding Wittgenstein } \\ 8 & 1973 / 74 & \text { Nature and Conduct } \\ 9 & 1974 / 75 & \text { Impressions of Empiricism } \\ 10 & 1975 / 76 & \text { Communication and Understanding } \\ 11 & 1976 / 77 & \text { Human Values } \\ 12 & 1977 / 78 & \text { Philosophèrs of the Enlightenment }\end{array}$

Volumes 1-5 and 10-12 are published by Harvester Press, Brighton and Volumes 6-9 are published by Macmillan, London.

$\begin{array}{rrl}\text { Volume } 13 & 1978 / 79 & \text { Idealism-Past and Present } \\ 14 & -1979 / 80 & \text { Marx and Marxisms } \\ 15 & 1980 / 81 & \text { Of Liberty } \\ 16 & 1981 / 82 & \text { Philosophy and Literature }\end{array}$

From Volume 13 onwards the Series will be published by Cambridge University Press. Volumes 13 and 14 were published in 1982 and Volumes 15 and 16 are published in 1983.

(C)The Royal Institute of Philosophy 1983 CAMBRIDGE UNIVERSITY PRESS

The Pitt Building, Trumpington Street, Cambridge CB2 1RP 32 East 57th Street, New York, N.Y. 10022 